DOI https://doi.org/10.18551/rjoas.2018-03.08

\title{
INDONESIAN CUSTOMER SATISFACTION IN ONLINE SHOPPING TRADING
}

\author{
Hermawan Francisca*, Wijayanti Sri Hapsari \\ Faculty of Economy and Business, Atma Jaya Catholic University, Indonesia \\ *E-mail: fr.hermawan@yahoo.com
}

\begin{abstract}
This research aims to find out if the ease of shopping, site design, informative, comprehensive, and communication have a significant influence on the level of Indonesian customer satisfaction in online shopping transactions and how the impact to the word of mouth communication. Respondents of this study are the 250 students of Jakarta colleges. This study found that the variables of design, simplicity, and security have an influence on customer satisfaction in shopping online, while the informative variable and communication have no influence on the customer's satisfaction online shopping.
\end{abstract}

\section{KEY WORDS}

Customer, satisfication, online shopping, communication.

There are many reasons why the community prefers to shop online transaction versus offline transaction at this time. First, the existence of the ease of the purchase or sale of a product gets is not limited by space. Second, the variety of products offered. Third, the buying process and decision making can be done easily. Fourth, the ease offered by online commerce more promising by looking the product that is already accessible to buyers, and can be reviewed by other customers. Online shopping site should also provide a guarantee of safety for consumers in conducting transactions, such as maintaining the privacy of the consumer, and timely product delivery assurance (Hoffman \& Novak, 2000). In other words, the guarantee of the security of the transaction the customer become the main factor that has been held by online merchants.

The last few years, online stores have grown in Indonesia, for example, kaskus.co.id, lazada.co.id, olx.co.id, and berniaga.com. The mall also presented online such as the website of blibli.com and matahari.com. The growth of the internet in Indonesia is a huge opportunity for online merchants and buying and selling of products supported by the ease of shipping goods via courier services, such as Tiki, JNE, and instant courier services offered i.e., Go-Jek and Grab. Word of mouth communication, provide information for prospective consumers who had never shopped online, feel more secure in the shopping, so need service to customers are constantly given.

This study aims to analyze whether the ease of shopping, site design, informative, comprehensive, and communication have a significant influence on the level of customer satisfaction in doing online shopping transactions and how its influence on the communication of the word of mouth.

\section{LITERATURE REVIEW}

Customer satisfaction is someone's feeling about likes or dislikes against a product after comparing the actual performance of the product with the expected performance (Kotler, 2003). Our satisfaction commitment affects online shopping (e-commitment) that can encourage the occurrence of communication is word of mouth (WOM) (Mukherjee \& Nath, 2007).

The convenience of the users of online sites that reflect detail information regarding the products, goods or services effect on customer's satisfaction. If the site is difficult to navigate and there is less relevant content, the user will easily switch to another site (Reichheld \& Scheffer, 2000). The appearance of online retail, graphics or image needs to be made in order to attract consumers who visited these sites were interested to explore it (Lohse\& 
Spiller, 1998). Navigation, product information, and design of the site are an important factor in creating customer satisfaction online (Szymanski \&Hise, 2000). This opinion is supported by the Page and Lepkowska-Whitc (2002), Ranganathan and Ganapathy (2002) which showed a site design influences towards customer satisfaction.

Another important variable is the quality of information about the product or service provided (Widow et al., 2002; Szymanski \&Hise) on the drop. The accuracy of information is a very important element for the credibility of the site. Consumers will benefit most from an information if it considers that such information is accurate (Cheung et al., 2008). The last dimension of the quality of information is comprehensive. Cheung et al. (2008) found that the more complete the information provided by the site, the higher the benefits that will accrue to the users of the site. The informative site may encourage consumer satisfaction in shopping online.

Lee and Turbans (2001) state that the consumer is unlikely to make a purchase online if it faces consequences were concerned. Therefore, the drop in security in shopping online is worthy of note because security refers to security technology, such as the presence of privacy, verification, and encryption mechanisms (Mukherjee \& Nath, 2007). Marketers need to assure prospective consumers that transactions they do safety.

The other variable is a communication. Communication includes openness, quality of information, and the quality of response (Mukherjee \& Nath, 2003). Gefen and Straub (2001) found that electronic systems are very important to build consumer trust online shopping. The quality of the response refers to the speed and frequency of communication in responding to the case.

Communication is the phenomenon of WOM group, an exchange of thoughts or ideas between two or more persons (Bone, 1992). Communication is more trusted than WOM advertising or information provided through the corporate promotion (Silverman, 2001).

E-WOM is communication, both containing a positive or negative message, made by consumers regarding product or company through internet media (Hennig-Thurau et al.,) the number of consumers shopping online was $83 \%$ of online consumers reported that they make a purchase based on the results of the review and the recommendations of other consumers online (Opinion Research Corporation, 2008, referenced in Cheung \& Thadani, 2010).

\section{CONCEPTUAL FRAMEWORK AND RESEARCH HYPOTHESES}

The conceptual framework in this study can be described in Figure 1.

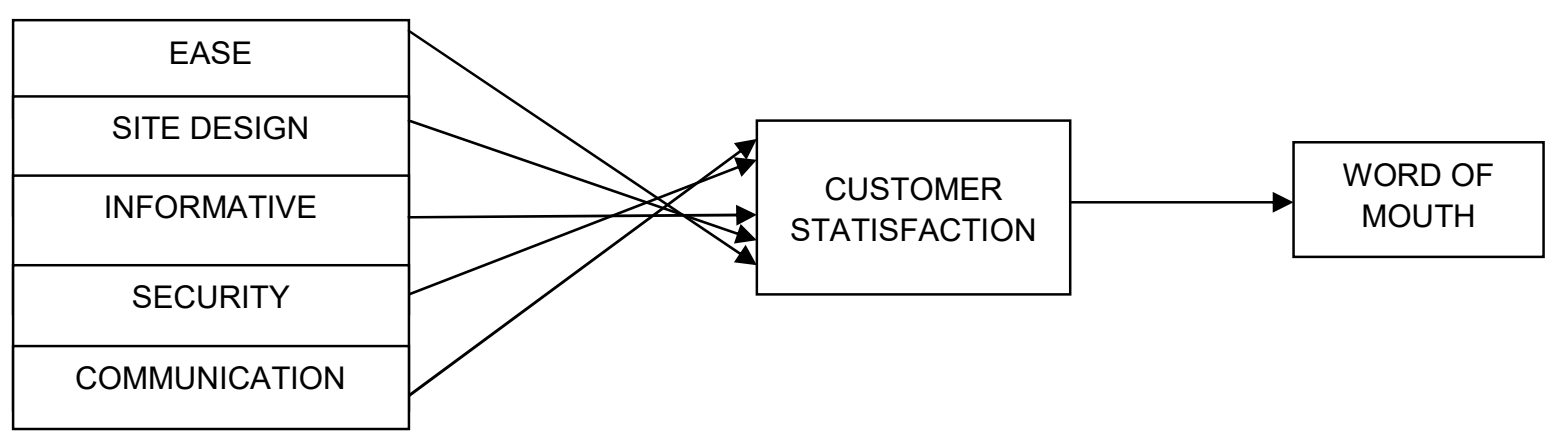

Figure 1 - Model Research

The hypothesis developed in this study are below.

$\mathrm{H} 1$ : the ease of shopping online has a significant and positive influence towards customer satisfaction.

$\mathrm{H}$ 2: the design of online shopping site has a significant and positive influence towards customer satisfaction 
H3: informative online shopping site has a significant and positive influence towards customer satisfaction

H4: security online shopping site has a significant and positive influence towards customer satisfaction

$\mathrm{H} 5$ : communication in the online shopping site has a significant and positive influence towards customer satisfaction

H6: customer satisfaction online shopping has significant effects on communication is word of mouth.

\section{METHODS OF RESEARCH}

The population of this study is an experienced Indonesia community shopping over the internet. Data collection was done through the dissemination of questionnaires that were adopted from Chung and Shin $(2010,2009)$. The questionnaires distributed to 250 students at several universities in Jakarta. Sampling techniques using a convenience sampling. An indicator is said to be valid if it has a value of corrected item-total correlation of 0.30 . Measurements of a variable are said to be reliable if it has a value of Cronbach alpha 0.60 .

\section{RESULTS AND DISCUSSION}

Reliability test results showed that all variables used in this study are reliable. It can be seen from Alpha Cronbach's value of each variable is greater than 0.7 (see Table 1).

Table 1 - Summary of Reliability test results $(n=250)$

\begin{tabular}{cc}
\hline Variabel & Nilai Cronbach's Alpha \\
\hline Ease & 0.783 \\
Site Design & 0.842 \\
Informative & 0.795 \\
Security & 0.868 \\
Communication & 0.776 \\
Consumer Statisfaction & 0.856 \\
\hline
\end{tabular}

Table 2 - Summary of the validity of the test results $(n=250)$

\begin{tabular}{|c|c|c|c|}
\hline Variabel & Question item & r-count & $\begin{array}{c}\text { r-table } \\
(\mathrm{df}=248, \alpha=5 \%)\end{array}$ \\
\hline \multirow[t]{4}{*}{ Ease } & This site is comfortable to use & 0.593 & 0.1241 \\
\hline & It takes a short time to shop on this site & 0.598 & 0.1241 \\
\hline & This site provides the ease of booking procedure & 0.645 & 0.1241 \\
\hline & $\begin{array}{l}\text { People who make a purchase on this site do not require the } \\
\text { assistance }\end{array}$ & 0.538 & 0.1241 \\
\hline \multirow[t]{4}{*}{ Site Design } & The site is visually appealing & 0.694 & 0.1241 \\
\hline & This site has a good selection of content & 0.720 & 0.1241 \\
\hline & The look of the site owned by professional & 0.690 & 0.1241 \\
\hline & This design is easy to understand when doing transaction & 0.603 & 0.1241 \\
\hline \multirow[t]{4}{*}{ Informative } & Provides information about the features and products that are sold & 0.569 & 0.1241 \\
\hline & $\begin{array}{l}\text { Provide accurate information about the features and quality of the } \\
\text { product }\end{array}$ & 0.646 & 0.1241 \\
\hline & $\begin{array}{l}\text { Provide various types of information (payment, shipping, and } \\
\text { returns }\end{array}$ & 0.556 & 0.1241 \\
\hline & Provides good information about products offered & 0.657 & 0.1241 \\
\hline \multirow[t]{4}{*}{ Security } & I feel safe transacting on this site & 0.629 & 0.1241 \\
\hline & My privacy is protected on this site & 0.782 & 0.1241 \\
\hline & $\begin{array}{l}\text { I believe that this site will not be misappropriated personal } \\
\text { information }\end{array}$ & 0.738 & 0.1241 \\
\hline & $\begin{array}{l}\text { I believe that this site will not provide my personal information to } \\
\text { other sites without my permission }\end{array}$ & 0.742 & 0.1241 \\
\hline \multirow[t]{4}{*}{ Communication } & Consumers can file complaints or ideas on this site & 0.651 & 0.1241 \\
\hline & This site has a good terms and conditions & 0.519 & 0.1241 \\
\hline & Customers can review products on this site are actively & 0.612 & 0.1241 \\
\hline & This site delivers unrivalled freedom to exchange thoughts & 0.544 & 0.1241 \\
\hline \multirow[t]{3}{*}{ Customer Statisfaction } & I am satisfied with the offer that is available on this site & 0.703 & 0.1241 \\
\hline & I am satisfied with the method of purchases made on this site & 0.792 & 0.1241 \\
\hline & I am satisfied with the product that I purchased on this site & 0.696 & 0.1241 \\
\hline
\end{tabular}


From Table 2, it can be seen the $r$ value calculated for all items larger questions of values of r-table. As such, all item variable questions to ease, site design, informative, security, communication, and consumer satisfaction are valid.

The results of the test of normality with the Kolmogorov Smirnov shows p-value $0244>$ alpha 0.05 so that it can be concluded that the residual value is normally distributed. In other words, the regression models meet the assumptions of normality of the data. Obviously, this can be seen in Table 3:

Table 3 - Data Normality Test Results

\begin{tabular}{lll}
\hline & & RES_1 Unstandardized Residual \\
\hline $\mathrm{N}$ & & 250 \\
Normal Parameters $^{\mathrm{a}}$ & Mean & 0.0000000 \\
& Std. Deviation & 1.40409441 \\
Most Extreme Differences & Absolute & 0.065 \\
& Positive & 0.065 \\
& Negative & -0.043 \\
Kolmogorov-Smirnov $Z$ & & 1.025 \\
Asymp. Sig. (2-tailed) & & 0.244 \\
a. Test distribution is Normal. & &
\end{tabular}

Heteroscedastic testing is done using graph scatterplot to see if the entire residual or error has the same variant for the entire observation over the independent variable. The table indicates that the Predicted Value Component Regression shows a random pattern so there were no heteroscedastic on the model of research.

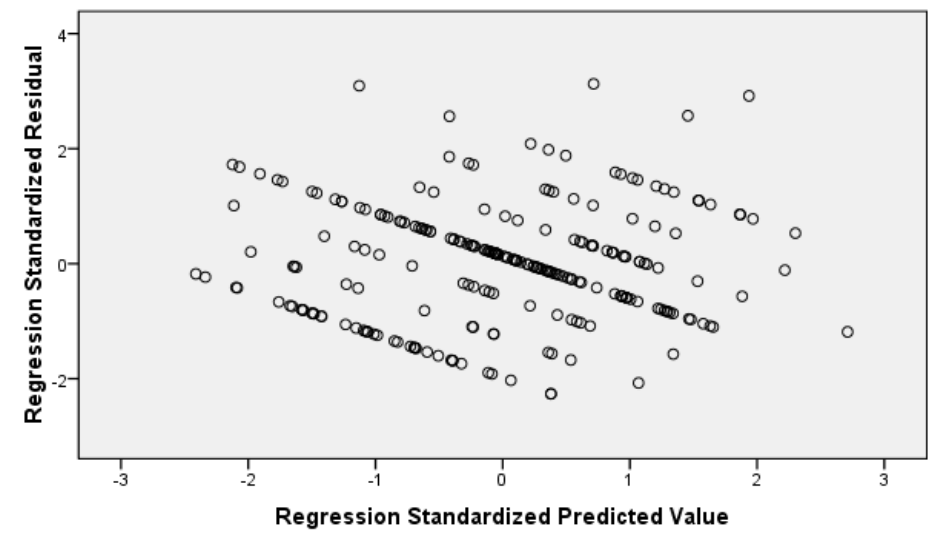

Figure 1 - The results of a test Scatterplot

Table 4 - Multicollinearity Test Results

\begin{tabular}{|c|c|c|c|c|c|c|c|}
\hline \multirow[b]{2}{*}{ Model } & \multicolumn{2}{|c|}{ Unstandardized Coefficients } & \multirow{2}{*}{$\begin{array}{l}\text { Standardized Coefficients } \\
\text { Beta }\end{array}$} & \multirow[b]{2}{*}{$\mathrm{T}$} & \multirow[b]{2}{*}{ Sig. } & \multicolumn{2}{|c|}{ Collinearity Statistics } \\
\hline & $\mathrm{B}$ & Std. Error & & & & Tolerance & VIF \\
\hline 1 (Constant) & 0.753 & 0.516 & & 1.458 & 0.146 & & \\
\hline X1 Ease & 0.177 & 0.047 & 0.209 & 3.777 & 0.000 & 0.851 & 1.175 \\
\hline X2 Site Design & 0.095 & 0.047 & 0.125 & 2.025 & 0.044 & 0.685 & 1.459 \\
\hline X3 Informative & 0.005 & 0.042 & 0.007 & 0.129 & 0.897 & 0.851 & 1.175 \\
\hline X4 Security & 0.269 & 0.046 & 0.371 & 5.784 & 0.000 & 0.635 & 1.575 \\
\hline X5Communication & 0.079 & 0.040 & 0.107 & 1.959 & 0.051 & 0.881 & 1.135 \\
\hline
\end{tabular}

Dependent Variable: Y1 Customer Statisfaction 
The independent variables have no tolerance and values when multicollinearity VIF approaching 1 (Ghozali, 2006). Table 4 shows the value of tolerance nothing less than 0.10 and VIF nothing greater than 10 so it can be concluded that there is no multicollinearity among the independent variables.

The value of the DW of 1,899 in Table 5 indicates that the value is between the value of du (1.8199) and 4-du (2.1801) so it can be concluded that there is no autocorrelation in regression models.

Table 5 - Autocorrelation Test

Model Summary

\begin{tabular}{llllll}
\hline Model & $\mathrm{R}$ & $\mathrm{R}$ Square & Adjusted R Square & Std. Error of the Estimate & Durbin-Watson \\
\hline 1 & $0.603^{\mathrm{a}}$ & 0.363 & 0.350 & 1.418 & 1.899 \\
\hline
\end{tabular}

a. Predictors: (Constant), X5 Communication , X2 Site Design, X3 Informative, X1 Ease , X4 Security

b. Dependent Variable: Y1 Customer Statisfaction

To perform an analysis of the influence of all the variables are independent of the level of voluntary disclosure, performed statistical tests or ANOVA $F$ test done which results are shown in Table 6. Based on Table 6 , it is known that the value of $F$ is the count of significance with the value 000027,823 far below the 0.05 value then it can be inferred that the regression model can be used to predict the level of consumer satisfaction online trading in this research. In other words, the whole independent variables simultaneously affecting the level of consumer satisfaction online trading in this study.

In addition, Table 7 also shows the value of the coefficient of determination (Adjusted $\mathrm{R}$ Square) of 0.35 . It showed that about $35 \%$ of the variation of the independent variables included in this study may explain the dependent variables, the remaining $65 \%$ is explained by other variables that are outside the model or not tested in this study.

Table 6 - Anova Test Results

\begin{tabular}{llllll} 
ANOVA $^{\mathrm{b}}$ & \multicolumn{3}{l}{} \\
\hline Model & Sum of Squares & df & Mean Square & F & Sig. \\
\hline 1 Regression & 279.885 & 5 & 55.977 & 27.823 & $.000^{\mathrm{a}}$ \\
Residual & 490.899 & 244 & 2.012 & & \\
Total & 770.784 & 249 & & & \\
\hline
\end{tabular}

a. Predictors: (Constant), X5 Communication , X2 Site Design , X3 Informative, X1 Ease , X4 Security

b. Dependent Variable: Y1 Customer Statisfaction

Table 7 - Determination Of Coefficient Of Test Results

Model Summary

\begin{tabular}{lllll}
\hline Model & $\mathrm{R}$ & $\mathrm{R}$ Square & Adjusted R Square & Std. Error of the Estimate \\
\hline 1 & $0.603^{\mathrm{a}}$ & 0.363 & 0.350 & 1.418 \\
\hline
\end{tabular}

a. Predictors: (Constant), X5 Communication , X2 Site Design , X3 Informative , X1 Ease , X4 Security

Table 8 presents the results of the test data $t$ of each independent variable are examined. The test results show that only the dimension design, simplicity, and security of sites that have an influence on the online shopping because of customer satisfaction has significance below 0.05 , whereas the dimension of the informative and communication have no influence customer satisfaction online trading.

Table 9 shows the value of significance from the ease of the site of 0.000 , smaller than 0.05. Thus the results of this study support Szymanski and Hise, 2000; Srinivasan et al., 2002; and Chung and Shin, 2008 indicate that the ease of the site has a significant influence on the level of satisfaction of consumers shopping online. The ease of the site effect on 
satisfaction because if your site is difficult to navigate and there is a less relevant content, then the user will be easy to move to see another site (Reichheld \& Scheffer, 2000) and because the consumers use online retail shopping to obtain ease of transactions (Torkzadeh \& Dhillon, 2002).

Table 8 - The t-test results

Coefficients $^{a}$

\begin{tabular}{llllll}
\hline \multirow{2}{*}{ Model } & \multicolumn{2}{l}{ Unstandardized Coefficients } & Standardized Coefficients & & \\
\cline { 2 - 5 } 1 & $\mathrm{B}$ & Std. Error & Beta & & Sig. \\
\hline X1 Ease & 0.753 & 0.516 & & 1.458 & 0.146 \\
X2 Design & 0.177 & 0.047 & 0.209 & 3.777 & 0.000 \\
X3 Informative & 0.095 & 0.047 & 0.125 & 2.025 & 0.044 \\
X4 Security & 0.005 & 0.042 & 0.007 & 0.129 & 0.897 \\
X5 Communication & 0.269 & 0.046 & 0.371 & 5.784 & 0.000 \\
\end{tabular}

Dependent Variable: Y1 Customer Statisfaction

Table 9 shows the value of significance of site design of 0.044 , smaller than 0.05 . Thus the results of this study show that the design of the site has a significant influence on the level of satisfaction of consumers shopping online. The results of this study similar with Page and Lepkowska-Whitc (2002); Ranganathan and Ganapathy (2002); Loshe and Spiller (1998) which show the existence of a site design influences towards customer satisfaction. An interesting site design (graphics or images) support the appearance of a retail online so consumers who visit the site will be keen to explore it (Lohse and Spiller, 1998). Good site design, neat, and easy navigation and fast can satisfy consumers because it can save you time in the shop and do not drain the minds of consumers in conducting transactions (Pastrick, 1997; Szymanski \& Hise, 2000).

The value significance of the informative site of 0897 far greater than 0.05 so the informative site has no influence on the level of satisfaction of consumers shopping online. The results of this study do not support the hypothesis.

The data in Table 9 show the value of significance of site security of 0.000 , smaller than 0.05 . It indicates that site security has a significant influence on the level of satisfaction of consumers shopping online. The results of this study are the same with Hoffman and Novak (2000), Reichheld and Schefter (2000), and Chung and Shin (2010) whose state that the security of the transaction in an online shopping system is an important factor to attract customers considering security a retail site that will effect on customer satisfaction. Site security related consumer concerns over the risk of reducing the losses that may be encountered (Lee \& Turbans, 2001) and make consumers unprotected from a side of privacy and security (Udo, 2001).

Table 9 also shows values the significance of communications site of 0.050 , equal to 0.05. Thus the results of this study indicate that communication site does not have a significant influence on the level of satisfaction of consumers shopping online. Communication in the site in the form of disclosure, provision of information that is authentic, relevant, and quality, as well as adequate feedback systems, are proven to encourage consumer satisfaction. The results of this study do not support the hypothesis of Joines et al. (2003) which showed that the tendency of internet users to do online shopping related to motivational communication and also the results of research Chung and Shin (2010) which showed that communication encourages the creation of customer satisfaction.

\section{CONCLUSION}

The results of this study show that only the dimension of ease, security, and design influence on the satisfaction of customers shopping online because they have a value of 
significance below 0.05 , whereas the dimension of the informative and communication do not influence on customer satisfaction online trading.

\section{REFERENCES}

1. Boulding, W., A. Kalra, R. Staelin, and VA.Zeithaml. 1993. A dynamic process model of service quality: From expectations to behavioural intentions. Journal of Marketing Research.30 (February).

2. Casalo, LV., C. Flavian, and M. Guinaliu. 2008. The role of satisfaction and website usability in developing customer loyalty and positive word-of-mouth in the ebanking services. The International Journal of Bank Marketing, 26 (6).

3. Cheung, CMK., MKO. Lee, and N. Rabjohn. 2008. The impact of electronic word of mouth: The adoption of online opinions in online customer communities. Internet Research.18 (3).

4. Chung, Ki Han and Jae Ik Shin. 2008. The relationship among e-retailing attributes, esatisfaction and e-loyalty. Management Review: An International Journal. 3 (1).

5. Chung. 2009. The relationship between site characteristics, relationship quality, and word of nouth. International Journal of Business and Information. 4(2)

6. Chung. 2010. The antecedents and consequents of relationship quality in internet shopping. Asia Pacific Journal of Marketing and Logistics. 22 (4).

7. Duhan, DF., SD. Johnson, JB.Wilcox, and GD. Herrel. 1997. Influence of consumer use of word of mouth recommendation sources. Journal of the Academy of Marketing Science. 25.

8. Fullerton, G. 2003. When does commitment lead to loyalty?Journal of Service Research. 5 (May).

9. Gefen, D., and Straub, D. 2001. Managing user trust in B2C e-services. e-Service Journal. 1 (1).

10. Hess, J., and Story, J. 2005. Trust-based commitment: multidimensional consumerbrand relationships. Journal of Consumer Marketing.22 (6).

11. Hoffman, DL. and Novak, T.P. 2000. How to acquire customers on the web. Harvard Business Review, May-June. 179-88.

12. Horppu, M., O. Kuivalainen, A. Tarkiainen, and H-K.Ellonen. 2008. Online satisfaction, trust and loyalty, and the impact of the offline parent brand. Journal of Product \& Brand Management.17 (6).

13. Janda, S., PJ.Trocchia, and K.P. Gwinner. 2002. Consumer perceptions of internet retail service quality. International Journal of Service Industry Management. 13 (5)

14. Joines, J., C. Scherer, and D. Scheufele. 2003. Exploring motivation fo consumer web use and their implications for ecommerce. Journal of Consumer Marketing.20 (2).

15. Kotler, P. 2003. Marketing Management. New Jersey: 11th Ed. Prentice Hall International Edition.

16. Lee, MKO., and Turban,E.. 2001. A trust model for consumer internet shopping. International Journal of Electronic Commerce.6 (1).

17. Lee, J., Park, D.H. \& Han, I. (2008). The effect of negative online consumer reviewson product attitude: An information processing view. Electronic Commerce Research and Applications, 7(3)

18. Lohse, GL., and Spiller, P. 1998. Electronic shopping. Communications of the ACM.41 (7)

19. Madu, CN., and Madu, AA.. 2002. Dimensions of e-quality. International Journal of Quality and Reliability Management.19 (3).

20. Mangold, WG.,Miller,F., and Brockway,GR.. 1999. Word of mouth communication in the service marketplace. The Journal of Service Marketing. 13. 73-87.

21. Morgan, RM., and Hunt, SD. 1999. Relationship- based competitive advantage: the role of relationship marketing inmarketing strategy. Journal of Business Research. 46. 
22. Mulia, AS., Francisca H, and Benedicta PE. 2017. Feasibility analysis of business: Case study in Indonesia minimarket. International Journal of Pure and Applied Mathematics. 117 (15).

23. Nah, FF-H., and Davis. S. 2002. $\mathrm{HCl}$ research issues in e-commerce. Journal of Electronic Commerce Research.3 (3).

24. Page, C., and E. Lepkowska-White. 2002. Web equity: a framework for building consumer value in online companies. Journal of Consumer Marketing.19 (3).

25. Pastrick, G. 1997. Secrets of great site design. Internet User. Fall. 80-87.

26. Ranganathan, C., and Ganapathy, S. 2002. Key dimensions of business-to-consumer web sites. Information \& Management.

27. Ringen, PH. 1987. A word of mouth network.Advances in Consumer Research, 14.

28. Silverman, G. 2001. The power of word of mouth. Direct Marketing, 64.

29. Srinivansan, SS., R. Anderson, and K. Ponnavolu. 2002. Customer loyalty in ecommerce: an exploration if its antecedents and consequence. Journal of Retailing. $78(1)$.

30. Torkzadeh, G., and Dillon, G. 2002. Measuring factors that influence the success of internet commerce. Information Systems Research.13 (2).

31. Udo, GJ. 2001. Privacy and security ecommerce: A survey study. Information Management \& Computer Security.9 (4).

32. Wixom, BH., and Todd, PA. 2005. A theoritical integration of user satisfaction and technology acceptance. Information Systems Research.16 (1). 